\title{
Pemanfaatan Eceng Gondok Sebagai Pengikat Logam Berat Pada Air Sungai Kahayan Di Kota Palangka Raya
}

\author{
Sri Rahayu \\ SMAN 5 Palangka Raya, Jalan Tingang Km 3,5, Palangka Raya 73112, Indonesia \\ email: ayu.sman5plk@gmail.com
}

\begin{abstract}
Abstrak. Pencemaran lingkungan, terutama air sungai, mencuat sejak beberapa dekade yang lalu seiring dengan merebaknya penambangan liar emas terutama di daerah hulu Sungai Kahayan. Air raksa sebagai pengikat dan pemurni dalam penambangan emas disadari memiliki dampak negatif yang lebih besar, yaitu mencemari air sungai. Masyarakat yang menempati bagian hilir sungai dan perusahaan air minum mau tidak mau memanfaatkan air yang sudah tercemar. Makalah ini akan membahas pemanfaatan eceng gondok yang dianggap sebagai tanaman pengganggu dialihfungsikan sebagai pengikat logam berat pada air sungai yang tercemar. Tujuan yang ingin dicapai ialah memaksimalkan sumber daya alam lokal yang melimpah, yaitu eceng gondok, untuk mengoptimalkan kebermanfaatan sumber daya alam yang lain, yaitu air sungai. Alat dan bahan yang perlu disiapkan ialah serbuk eceng gondok yang dikemas dalam wadah teh celup dan sampel air Sungai Kahayan. Serbuk eceng gondok dicelupkan ke dalam air sampel tersebut dengan berbagai variasi waktu, yaitu 1, 6, 12, 24, dan 48 jam. Perubahan kemudian diamati dan dianalisis apakah konsentrasi air raksa dalam air Sungai Kahayan berkurang. Dari pengujian ini diharapkan eceng gondok dapat dimaksimalkan fungsinya, sementara ketersediaan air bersih yang bebas bahanbahan pencemar makin banyak.
\end{abstract}

Kata kunci: pencemaran air, logam berat, air raksa, eceng gondok 


\section{Pendahuluan}

Air merupakan zat yang sangat penting tidak hanya bagi manusia, tetapi juga bagi seluruh makhluk di dunia ini. Semua makhluk hidup memerlukan air sebagai salah satu zat yang memegang peran dan keberlangsungan hidup mereka. Tuhan telah menciptakan air dengan bentuk dan struktur kimiawi yang terbaik dan tepat. Fungsi air tidak hanya sebagai pelepas dahaga, tetapi juga merupakan pelarut bagi semua reaksi kimia.

Begitu pentingnya peran air dalam kehidupan sesungguhnya semakin menyadarkan manusia akan tanggung jawabnya, yaitu bagaimana menjaga air tetap bersih. Namun, semakin kompleksnya aktivitas dan dinamika kehidupan manusia di bumi semakin kompleks pula masalah yang dihadapi yang berkaitan dengan air. Singkat kata, air yang bersih semakin jarang tersedia.

Sungai Kahayan yang melintasi Kota Palangka Raya merupakan salah satu sungai terpanjang di Kalimantan Tengah. Darinya masyarakat di sepanjang DAS Kahayan memanfaatkan air sungai untuk berbagai keperluan. Golongan pengguna air sungai Kahayan beragam, mulai dari individu hingga perusahaan besar yang karena aktivitasnya memerlukan air dalam jumlah besar.

Kebersihan dan kualitas air Sungai Kahayan semakin diperhatikan dan dipermasalahkan. Begitu banyaknya pihak yang memanfaatkan aliran air Sungai Kahayan menimbulkan berbagai macam pendapat. Kualitas air Sungai Kahayan dari hari ke hari terus pula diperdebatkan dan dipolemikkan. Itu terbukti dari banyaknya tulisan di media tentang kualitas ekosistem Sungai Kahayan secara umum.

Beberapa dekade belakangan isu tentang kebersihan air Sungai Kahayan menghangat. Maraknya penambangan liar emas di daerah hulu Sungai Kahayan memicu betapa seriusnya pencemaran air sungai sebagai efek samping kegiatan penambangan. Tahun 2002 saja terdapat 1.097 penambangan emas tanpa izin (Peti) di sepanjang DAS Kahayan. Berapa banyaknya Peti yang sekarang beroperasi?

Semua kasus pencemaran merkuri selalu dikaitkan dengan penambangan emas. Hal itu dimaklumi mengingat penambangan emas menggunakan air raksa atau merkuri (Hydrargyrum) sebagai bahan atau zat pengikat dan pemurni emas. Harga air raksa dan kemudahan mendapatkannya menjadi pemicu semakin maraknya penggunaan air raksa. Efek yang kemudian timbul ialah tercemarnya air sungai.

Masyarakat yang berada di daerah hilir sungai merasakan dampaknya secara langsung. Bahkan, masyarakat yang tinggal di sepanjang DAS niscaya pula merasakan dampaknya. Dampak pendek atau efek jangka pendek mungkin belum terasa, namun akibatnya akan terakumulasi dalam jangka panjang.

Ekosistem yang hidup di dalam air sungai turut pula merasakan efek tercemarnya air. Ikan-ikan dan semua makhluk hidup yang setiap hari berada di lingkungan ekosistem perlahan-lahan tercemar. Akumulasi cemaran terkumpul di setiap bagian tubuh mereka. Dapat dibayangkan jika ikan yang tercemar dikonsumsi manusia. Manusia pulalah yang merasakan efek terbesar.

Pertanyaan selanjutnya ialah bagaimana, paling tidak, mengurangi konsentrasi cemaran air raksa pada air di Sungai Kahayan? Beberapa ahli telah melakukan identifikasi kadar cemaran air raksa pada Sungai Kahayan. Dikutip dari Borneo News, kandungan merkuri dalam sedimen sungai yang paling tinggi 
ialah DAS Kahayan, yaitu 0,215 mg/kg. Tim dari Lembaga Ilmu Pengetahuan Indonesia (LIPI) menemukan bahwa kandungan merkuri dalam sedimen Sungai Kahayan di enam titik mencapai 2,991-66,434 mg/kg. Angka itu jauh melampaui standar baku mutu sedimen Canadian Quality Guidelines for Threshold Effect Level (TEL), yaitu $0,13 \mathrm{mg} / \mathrm{kg}$.

Tim peneliti dari LIPI pada tahun 2006 juga mengadakan penelitian di Sungai Kahayan wilayah di antara Kota Palangka Raya dan Tewah, Gunung Mas. Diketahui kandungan merkuri pada air Sungai Kahayan di wilayah itu mencapai 0,0225 - 0,2350 gr/l. Dikutip dari Kompas.com, pencemaran merkuri di tiga sungai besar di Kalimantan Tengah, yaitu Sungai Kahayan, Kapuas, dan Barito, masuk dalam level membahayakan. Tingkat pencemaran merkuri di DAS Barito tertinggi di Sungai Tewah, yaitu 5,519 $\mu \mathrm{g} / \mathrm{l}$. Padahal, batas baku mutu konsentrasi merkuri hanya $2,000 \mu \mathrm{g} / 1$.

Di DAS Kahayan sendiri tingkat cemaran merkuri mencapai 2,996-4,687 $\mu \mathrm{g} / \mathrm{l}$ ditemukan di Bawan, Tanjung Sanggalang, Tumbang Rungan, Palangka Raya, Jabiren, dan Pulang Pisau. Yang terparah adalah DAS Kapuas yang mencakupi wilayah Mentangai, Kuala Kapuas, Timpah, dan Masaran Hulu. Konsentrasi merkuri di daerah-daerah itu mencapai rata-rata 7,029 $\mu \mathrm{g} / 1$.

Merkuri sangat berbahaya bagi kehidupan. Air yang tercemar merkuri sangat beracun. Akumulasi kandungan merkuri dalam tubuh dapat menyebabkan berbagai macam gangguan kesehatan yang berbahaya. Manusia memang tidak mungkin mengonsumsi merkuri secara langsung, tetapi melalui biota laut yang tubuhnya sudah tercemar merkuri, misalnya ikan, kerang, dan udang. Manusia yang mengonsumsi biota laut yang tercemar merkuri akan turut merasakan dampak buruk logam berat tersebut.

Berbagai penelitian dan eksperimen mengenai bagaimana mengurangi konsentrasi merkuri dan logam-logam berat lain telah dilakukan. Penelitian yang paling banyak dilakukan berkaitan dengan eceng gondok. Eceng gondok dianggap dapat mengikat logam berat dan secara bertahap menurunkan konsentrasi merkuri dalam air.

Tosepu meneliti laju penimbunan logam berat timbal dan kadmium dengan eceng gondok. Hasilnya timbal mampu diturunkan hingga nol persen pada hari ke-30 dan kadmium pada hari ke-24. Sumiyati dan Hadiwidodo meneliti tentang kebermanfaatan eceng gondok dalam menyerap logam krom. Mereka menyimpulkan bahwa eceng gondok efektif dalam menyisihkan krom mencapai lebih dari $76 \%$ pada hari ke-18.

Spesies eceng gondok (Eichornia crassipes) termasuk dalam genus eichornia dan famili pontederiaceae dianggap sebagai tumbuhan pengganggu atau gulma. Ia ditemukan pertama kali oleh Carl Friedrich Phillip von Martius pada tahun 1824 di Sungai Amazon. Pertumbuhannya yang sangat cepat menyebabkan ia dikenal sebagai tanaman pengganggu. Ia juga kerap kali dituduh sebagai penyebab menurunnya kadar oksigen dalam air.

Selain dikenal sebagai gulma, eceng gondok juga terbukti mampu menyerap logam berat, misalnya merkuri, kadmium, nikel, dan krom. Widyanto dan Susilo (1977) menyimpulkan bahwa dalam waktu 24 jam eceng gondok mampu menyerap merkuri sebanyak $1,77 \mathrm{mg} / \mathrm{g}$. Selain dapat menyerap logam berat, eceng gondok juga dapat menyerap residu pestisida. Eceng gondok juga bernilai ekonomis dengan menjadikannya briket bahan bakar dan barang-barang kerajinan. 
Penelitian ini akan menyelidiki efektivitas eceng gondok dalam mengikat logam merkuri pada air yang tercemar logam berat tersebut. Fokus masalah penelitian ini ialah seberapa efektif eceng gondok dapat menyerap merkuri pada air yang tercemar. Sampel air yang digunakan dalam penelitian ini ialah air sungai yang diambil dari bawah jembatan Sungai Kahayan di Kota Palangka Raya. Tujuan diadakannya penelitian ini ialah mengidentifikasi kemampuan eceng gondok dalam mengikat logam berat merkuri pada air yang tercemar. Manfaat penelitian ini ialah pemanfaatan kandungan lokal alami yang melimpah untuk mengoptimalkan sumber daya air sungai agar kualitasnya meningkat.

\section{Metode Penelitian}

Metode yang digunakan dalam penelitian ini ialah metode eksperimental laboratorium. Berdasarkan lokasi penelitian ini merupakan penelitian studi kasus yang hanya dilakukan di lokasi dan objek tertentu, yaitu air sungai di bawah Jembatan Kahayan. Alat dan bahan yang diperlukan ialah sampel berupa air Sungai Kahayan, eceng gondok berbentuk bubuk, alat pengukur konsentrasi merkuri, gelas ukur, blender, dan timbangan, serta beberapa alat laboratorium lain yang mendukung.

Teknik pengambilan sampel yang diterapkan dalam penelitian ini ialah purpossive random sampling, yaitu pemercontohan acak bertujuan. Teknik pengambilan sampel tersebut dilakukan untuk memenuhi tujuan penelitian ini sehingga air sungai yang dijadikan sampel ialah air Sungai Kahayan yang diambil dari bawah Jembatan Kahayan. Air sungai di bawah jembatan Kahayan dipilih berdasarkan data yang diperoleh dari tim peneliti LIPI. Konsentrasi merkuri pada air Sungai Kahayan di Kota Palangka Raya mencapai 2,996 $\mu \mathrm{g} / \mathrm{l}$.

Langkah-langkah yang ditempuh dalam melakukan penelitian ini ialah sebaga berikut. Pertama, mengumpulkan beberapa ikat eceng gondok untuk dikeringkan. Eceng gondok yang telah kering sempurna kemudian dihaluskan dengan blender. Hasil lumatan tersebut diperas dan diambil ampasnya. Ampas atau ekstrak eceng gondok yang terkumpul kemudian dikeringkan dan dikemas dalam beberapa wadah teh celup seberat kira-kira 5 gram.

Sampel air sungai yang telah disiapkan dibagi ke dalam 5 wadah gelas ukur masing-masing $200 \mathrm{ml}$. Air sampel kemudian diukur pH-nya dengan $\mathrm{pH}$-meter dan konsentrasi merkuri sebelum perlakuan dengan alat pengukur. Sampel air yang telah diketahui konsentrasi merkurinya kemudian dicelupi satu kantong eceng gondok kering. Durasi dan variasi waktu pencelupan kemudian ditetapkan, yaitu 1 jam, 6 jam, 12 jam, 24 jam, 48 jam. Setelah waktu yang ditentukan terpenuhi, air sampel diukur konsentrasi merkurinya dengan SSA kemudian dibandingkan antara keadaan sebelum dan setelah perlakuan. Selisih konsentrasi merkuri sebelum dan sesudah perlakuaan kemudian dicatat.

\section{Hasil dan Pembahasan}

Penambangan emas ilegal atau yang lebih dikenal dengan istilah penambangan emas tanpa izin menimbulkan berbagai kontroversi dan pro kontra di samping memang meningkatkan taraf kehidupan para pelakunya. Kontroversi yang paling meresahkan berkaitan dengan pencemaran air sungai. Kita ketahui bahwa penambangan emas memerlukan atau sangat akrab dengan air. Dalam memurnikan dan mengikat emas para petambang menggunakan merkuri atau air 
raksa. Harga yang murah dan kemudahan mendapatkannya menjadikan pemanfaatan air raksa merebak.

Berdasarkan analisis yang telah dilakukan, penulis menyimpulkan beberapa hal. Level konsentrasi merkuri pada air sampel diketahui 2,996 $\mu \mathrm{g} / 1$ atau kurang lebih 0,003 mg/l. Padahal, menurut Permenkes Nomor 82 Tahun 2001 standar baku mutu kandungan merkuri pada air maksimal $0,001 \mathrm{mg} / \mathrm{l}$ atau kurang lebih 1 $\mu \mathrm{g} / \mathrm{l}$. $\mathrm{pH}$ air sungai atau air sampel mungkin berpengaruh dalam proses, tetapi tidak dipertimbangkan dalam makalah ini.

Setelah dilakukan pengujian dengan berbagai variasi waktu, penulis mendapati data berikut. Sampel air yang pertama yang dicelupi eceng gondok selama 1 jam secara fisik tidak terjadi perubahan yang signifikan. Tidak adanya perubahan fisik ini pun terjadi pada semua air sampel. Tingkat konsentrasi merkuri pada air sampel pertama hanya turun kurang lebih $1,4 \%$ saja, yaitu menjadi 2,954 $\mu \mathrm{g} / \mathrm{l}$. Pada sampel pertama relatif tidak terjadi perubahan yang signifikan konsentrasi merkurinya.

Pada sampel kedua yang dicelupi eceng gondok selama 6 jam didapati penurunan konsentrasi merkuri yang juga kurang signifikan, yaitu kurang lebih $3,6 \%$. Konsentrasi merkuri pada sampel kedua ini menjadi 2,888 $\mu \mathrm{g} / \mathrm{l}$.

Pada sampel ketiga yang dicelupi eceng gondok selama 12 jam didapati perubahan konsentrasi merkuri yang belum termasuk signifikan, hanya sekitar 5,2\%. Konsentrasi merkuri pada sampel ketiga ini menjadi 2,840 $\mu \mathrm{g} / 1$.

Pada sampel keempat yang dicelupi eceng gondok selama 24 jam didapat perubahan konsentrasi merkuri mencapai sekitar 7,1\% sehingga konsentrasi merkuri pada sampel tersebut mencapai $2,783 \mu \mathrm{g} / 1$.

Sampel kelima yang dicelupi eceng gondok selama 48 jam memperlihatkan perubahan yang dirasa cukup signifikan. Selain sedikit perubahan fisik, perubahan konsentrasi merkuri juga lebih besar dibanding empat sampel sebelumnya. Pada sampel kelima ini konsentrasi merkuri menurun hingga hampir menyentuh angka $10 \%$, atau tepatnya $9,3 \%$. Konsentrasi merkuri pada sampel terakhir ini menjadi $2,717 \mu \mathrm{g} / \mathrm{l}$.

Berdasarkan data berikut penulis menyimpulkan bahwa waktu sangat menentukan tingkat penurunan merkuri pada sampel. Semakin lama waktu pencelupan semakin besar persentase penurunan konsentrasi merkuri dalam ar sampel. Sampel terakhir yang paling lama dicelupi eceng gondok menunjukkan perubahan yang paling signifikan.

Bobot eceng gondok yang digunakan dalam makalah ini sekitar 5 gram. Penambahan eceng gondok diperkirakan akan memangkas waktu turunnya kadar konsentrasi merkuri dalam sampel. Jadi, berat eceng gondok berbanding lurus dengan tingkat penurunan konsentrasi merkuri.

Berlandaskan analisis pula dapat diketahui bahwa eceng gondok memang terbukti mampu menyerap logam berat, termasuk merkuri. Namun, seperti bahanbahan alami yang lain, efek yang ditimbulkannya terbilang lambat dan memerlukan waktu yang lama. Konsumsi waktu yang lama dalam pemurnian air dari logam berat dipandang kurang efektif jika dibandingkan laju pencemaran air sungai oleh merkuri yang terbilang sangat cepat.

\section{Simpulan}

Pencemaran air oleh merkuri bukan lagi isu daerah, melainkan isu nasional bahkan internasional. Begitu masifnya penggunaan merkuri dalam penambangan 
emas di berbagai daerah memicu buruknya tingkat pencemaran air sungai dan air tanah. Pembahasan tidak hanya berhenti pada tataran air sungai dan air tanah. Air sungai yang akhirnya bermuara ke laut akan mencemari laut pada akhirnya. Kerusakan dan pencemaran tidak hanya melanda biota sungai, tetapi juga biota laut. Air tanah yang sudah tercemar merkuri pun meracuni mereka yang menggunakannya.

Buruknya penanganan penambangan emas terutama yang tanpa izin memperburuk masalah ini. Pemerintah seolah-olah takberdaya menghadapi para penambang emas yang biasanya merupakan pengusaha-pengusaha lokal. Kebijakan pengendalian penambangan emas hanya berhenti di atas meja dan tidak diikuti implementasi yang berkelanjutan. Hal seperti ini tidak bisa dibiarkan mengingat air baik masa sekarang maupun nanti masih sangat penting perannya bagi manusia dan makhluk lain. Air yang tercemar dan tidak sehat tentu membahayakan kehidupan generasi selanjutnya.

Berdasarkan analisis dan pembahasan yang telah diuraikan di atas diketahui bahwa eceng gondok terbukti efektif dalam mengikat logam berat merkuri. Namun, waktu yang diperlukan untuk memurnikan air yang sudah tercemar itu relatif lama dan kurang efisien. Meskipun demikian, hal tersebut perlu dilakukan mengingat cara ini merupakan alternatif yang paling ekonomis dan mudah dilakukan.

Beberapa masalah dalam menyusun makalah ini perlu penulis kemukakan. Penelitian ini tidak mempertimbangkan $\mathrm{pH}$ sampel. Ke depan diharapkan dilakukan penelitian yang memperihatkan bahwa $\mathrm{pH}$ air sampel juga memengaruhi proses penurunan kadar merkuri dalam sampel. Selain $\mathrm{pH}$, adanya kesalahan prosedur dalam penelitian ini juga dimungkinkan. Dengan kata lain, penelitian lanjutan dengan proses yang baik dan prosedur yang baku hendaknya dilakukan untuk dapat mengidentifikasi keunggulan eceng gondok dalam menyerap logam berat merkuri.

\section{Daftar Pustaka}

Sumiyati, Sri \& Mochtar Hadiwidodo. (2007). Pemanfaatan Eceng Gondok dalam Penyisihan Logam Berat Chrom pada Limbah Elektroplating. Diperoleh dari http://www.ejournal.undip.ac.id/index.php/teknik/article/view/2076.

Tangio, Julhim S. (2013). Adsorpsi Logam Timbal dengan Menggunakan Biomassa Eceng Gondok. Diperoleh dari http://repository.ung.ac.id/get/simlit_res/1/1435/Adsorpsi-LogamTimbal-Pb-Dengan-Menggunakan-Biomassa-Eceng-Gondok.pdf.

Tosepu, Ramadhan. (2012). Laju Penurunan Logam Berat Plumbum dan Cadmium oleh Eichornia Crassipes dan Cyperus Papyrus. Diperoleh dari https://jurnal.ugm.ac.id/JML/article/view/18450.

Triana, Linda et. al. (2013). Analisis Cemaran Logam Berat Merkuri pada Air dan Udang di Sungai Mandor, Kabupaten Landak. Diperoleh dari http://ejournal.undip.ac.id/index.php/jkli/article/view/5024.

Yuliani, et. al. (2010). Analisis Akumulasi Timbal pada Eceng Gondok dari Beberapa Lokasi di Kota Makassar. Diperoleh dari http://repository.unhas.ac.id/bitstream/handle/123456789/14667/JURN AL.pdf? sequence $=1$ 